\title{
The Decline of the West (1908-1929): The Rupture of Time in Modernity and the Rise of the Prophets of Crisis
}

\author{
Student Years under Fascism and the Guidance of a Spiritual \\ Prophet of Crisis
}

It is no coincidence that de Martino published his first scholarly article as a twenty-one-year-old student at the University of Naples on Oswald Spengler's (1880-1936) The Decline of the West (1918), one of the most important books published during wwI. ${ }^{1}$ Although scholarship has lamented that "The Decline of the West" (La decadenza dell'Occidente) consists of only "two immature pages," ${ }^{2}$ and has hastily denied it the status of "insight, or, even less, formulation of specific hypotheses or theories,"3 it is of immense value to the historian of ideas. In fact, it is the starting point of what would become the marking trait of de Martino's thinking for the rest of his life, namely a profound fascination with the crisis of his own civilization.

Besides the fact that Ernesto de Martino was born in Naples on December 1st 1908, we do not know much about his childhood and upbringing. Ernesto's father, who gave his own name to his only son, was an engineer for the Italian State Railway, and his mother Gina Jaquinangelo was a teacher. About Ernesto Sr. it is said that he was secularized and patriotic. ${ }^{4}$ Introducing his mother, scholars emphasize that she was secular yet open to mediumistic and spiritualistic experiences. De Martino's family was required to move frequently due to the profession of the pater familias. As a consequence, the young Ernesto moved in between Florence, Naples, and Turin. After finishing the liceo,

1 Ernesto De Martino, "La decadenza dell'Occidente," Rivista del gruppo universitario fascista napoletano Mussolini I (1929): 28-29. For Spengler's original work, see Oswald Spengler, Der Untergang des Abendlandes: Umriss einer Morphologie der Weltgeschichte (Leipzig: Wilhelm Braunmüller, 1918).

2 Domenico Conte, "Ernesto De Martino e la 'mobilitazione dell'arcaico,"' in Ernesto De Martino tra fondamento e "insecuritas," ed. Giuseppe Cantillo, Domenico Conte, and Anna Donise (Napoli: Liguori, 2014), 96.

3 Giuseppe Galasso, "La funzione storica del magismo. Problemi e orizzonti del primo de Martino," Rivista storica italiana 2, no. cIX (1997): 494.

4 Cesare Bermani, "Tra furore e valore: Ernesto de Martino," Il De Martino-Bollettino dell'Istituto Ernesto De Martino 5-6 (1996): 35 . 
where he studied Latin and German, he enrolled at the Polytechnic University (Politecnico) to study Engineering in 1927. Having done so in order to please his father, he became quickly dissatisfied with this inherited course of studies. A year later, de Martino left the Piemontese capital to return with his family to Naples where he commenced his studies in philosophy and religion.

The ideas lived out by his parents - between religion and the nationthematically inform his early intellectual activities, which also move between these two concepts. In fact, de Martino's early explorations of religion were closely related to his political engagement with fascism. Not unlike their generous treatment of other eminent Italian historians of religion — such as Raffaele Pettazzoni (1883-1959) and Giuseppe Tucci (1894-1984) — scholars have been slow to grasp the weight of de Martino's youthful endeavors. ${ }^{5}$ In the case of de Martino, commentators have generally reduced his involvement with fascism to a mere outgrowth of the indoctrination in the Italy between the world wars. ${ }^{6}$

There is, of course, some evidence for such a reading. After the March on Rome in late October 1922 and Benito Mussolini's rise to power, the Duce quickly made the myth of Italy as new nation and as herald of cultural rebirth into his regime's "political program."7 To use a term coined by French sociologist Jean-Paul Willaime, Mussolini's fascism became an "état éducateur." In practice, this was nowhere more apparent than in his endeavors to portray fascism as a movement of youth and in his efforts to establish a program of political catechism. This led to "a gigantic operation of 'public relations' and 'social pedagogy',"9 which was first introduced in schools and universities, and then in other realms of culture, until it pervaded most sectors of Italian society. ${ }^{10}$

$5 \quad$ Michael Stausberg, "Raffaele Pettazzoni and the History of Religions in Fascist Italy (1928-1938)," in The Study of Religion under the Impact of Fascism, ed. Horst Junginger (Leiden: Brill, 2008), 365-86; Gustavo Benavides, "Giuseppe Tucci, Anti-Orientalist," in Asian Horizons: Giuseppe Tucci's Buddhist, Indian, Himalayan and Central Asian Studies, ed. Angelo Andrea Di Castro and David Templeman (Melbourne: Monash University Publishing, 2015), 3-15.

6 A notable exception is the recently published article by Roberto Alciati, in which the author clearly shows that de Martino's later theories of religion were already adumbrated in his writings on fascism as a civil religion. Roberto Alciati, "La religione civile di Ernesto de Martino," Studi e materiali di storia delle religioni 85, no. 1 (2019): 285-317.

7 Robert Wohl, The Generation of 1914 (Cambridge: Harvard University Press, 1979), 178.

8 Jean-Paul Willaime, "La religion civile à la française et ses métamorphoses," Social Compass 40, no. 4 (1993): 574.

9 Carlo Tullio Altan, Italia: una nazione senza religione civile. Le ragioni di una democrazia incompiuta (Udine: Istituto editoriale Veneto Friulano, 1995), 55.

10 Victoria De Grazia, The Culture of Consent: Mass Organization of Leisure in Fascist Italy (New York: Cambridge University Press, 1981), 16. 
De Martino entered the University of Naples in 1928 and immediately joined in the Neapolitan section of the GUF, ${ }^{11}$ the Fascist University Groups (Gruppi Universitari Fascisti), which served as the central vehicle for political persuasion in university education. Two years later he registered with the National Fascist Party (Partito Nazionale Fascista, PNF) and, in 1932, he joined the Blackshirts (Milizia Volontaria per la Sicurezza Nazionale). In her influential book, entitled Ernesto De Martino: Les vies antérieures d'un anthropologue (2009), the French anthropologist Giordana Charuty has convincingly shown that the newly established GUF were aimed at making university students into "apostles of the revolution [who] operate the pen just as well as the sword."12 The fascist groups offered the students many benefits, such as a center to study, a library, and medical services. Charuty notes that all of these were "measures of 'assistance' through which the regime favors the learning process of variant competences necessary for the progression within the new social hierarchies, while simultaneously endeavoring to exercise ideological control on the teachers as well as on the students."13 This being said, it is imperative to acknowledge that de Martino's fascism was much more than merely convenient opportunism. In fact, I will demonstrate that he regarded fascism as a result of and response to a profound crisis affecting the modern Western world.

As for his early intellectual formation, de Martino was shaped by a trident of teachers: Adolfo Omodeo (1889-1946), Raffaele Pettazzoni (1883-1959), and Vittorio Macchioro (1880-1958). In 1932, he defended his dissertation on Greek ritual practices under the supervision of his most official teacher, Italy's foremost historian of Christianity, Adolfo Omodeo. Two years later, as he proceeded to publish his research in Italy's preeminent journal for scholars of religion, Studies and Materials in the History of Religions (Studi e materiali di storia delle religioni), he did so upon the invitation of the journal's founder, the towering figure of religious studies in Italy, Raffaele Pettazzoni.

This being said, the theme of his earliest piece of academic scholarship, the "gephyrisms," ritual jeers performed on the bridge of Cephisus in Athens during the procession of the Eleusian mysteries, point to the third and most esoteric of de Martino's teachers. Vittorio Macchioro, indeed, wrote a highly influential book on Greek mystery religion by the name of Zagreus (1920/30), which offered an analysis of the paintings in the Villa of the Mysteries (Villa dei Misteri) in the Ancient Roman city of Pompei after their discovery in 1909.

11 Domenico Conte, "Decadenza dell'Occidente e 'fede' nel giovane de Martino," Archivio di storia della cultura 23 (2010): 486.

12 Charuty, Ernesto de Martino, 92-93.

13 Charuty, 93-94. 
The villa in the South of the peninsula is famous for a series of spectacular and well-preserved frescos. Pursuing a career as curator in archeological museums, Macchioro had privileged access to these frescos, which are generally believed to depict the initiation of a young woman into the Greco-Roman mystery cult. Largely due to the neglect by the official Italian academic world — unlike the two renowned professors at the universities of Rome and Naples, de Martino's third guide would never fulfil his dream of gaining access to a university position-Macchioro's massive impact on his student's thought has remained obscured for a long time. ${ }^{14}$ Considering that the creative interpreter of Greek religion was lecturing at some of the world's most prestigious institutions and cultivated contacts with such luminaries as Mircea Eliade and Aby Warburg, it is indisputable that he is one of the most underestimated Italian intellectuals of the twentieth century.

De Martino and Macchioro maintained a fertile correspondence that started in the summer of 1930 when de Martino was stationed as a military cadet in Northern Italy. It would last for nearly a decade and provide us with precious insights into a profound and complex relationship. After the initial letters in 1930, the correspondence was interrupted for almost five years during which Macchioro traveled to lecture throughout the world-particularly in Europe, the United States, and India. During this time, the teacher's career was "in full bloom,"15 while de Martino, finishing his dissertation in 1932 and making his first forays into religious studies journals in 1933 and 1934, matured from student to scholar. When their correspondence resumed, Macchioro still resided in India and prepared for his return to Trieste. De Martino, on the other hand, lived in the Southern Italian city of Bari where he taught history and philosophy at the Liceo Scientifico A. Scacchi. Around the same time, de Martino married his guru's favorite daughter Anna (1911-72), who after finishing her studies in art history became a teacher at the technical institute of Molfetta, in December 1935. Just as Mussolini and the women of his nation-giving up their gold wedding rings in exchange for rings of steel during the "Day of

\footnotetext{
14 Riccardo Di Donato, "Preistoria di Ernesto de Martino," in I greci selvaggi. L'antropologia storica di Ernesto de Martino (1989; repr., Roma: Manifestolibri, 1999), 17-40; Riccardo Di Donato, "Una preistoria rivisitata," in I greci selvaggi. L'antropologia storica di Ernesto de Martino (Roma: Manifestolibri, 1999), 139-55.

15 Riccardo Di Donato, "Introduzione: Dioniso in Europa. Esperienza e storia delle religioni," in Le intrecciate vie: carteggi di Ernesto de Martino con Vittorio Macchioro e Raffaele Pettazzoni, ed. Riccardo Di Donato and Mario Gandini, Carteggi, I; Anthropoi, 9 (Pisa: Edizioni ETS, 2015), 30.
} 
Faith" - entered into a "state of mystic communion,"16 the wedding between Ernesto and Anna played a unifying role in the relationship between him and his new father-in-law. Vittorio, isolated from his own family, was relying on his new son-in-law for some of his emotional connection with his daughter and wife, who lived with him in an apartment on Corso Vittorio Emanuele in Bari. With the birth of Ernesto's first daughter Lia in 1936, the bond between the two men deepened further. At this time, de Martino started to address his mentor no longer as "illustrious professor," but rather as "dear professor," "dear friend," and, finally, "dear Papa." The same is true for Macchioro who extended his paternity from his daughter to his son-in-law, signing every letter as "your father."

What strikes the reader of their correspondence is not its content, but rather the apocalyptic atmosphere, the prophetic hope, and the overall dramatic tone expressed therein. Macchioro's existence was marked by moments of intense crisis, religious experiences of rebirth, and radical metamorphosis. First and foremost amongst them was a "disheartening and aporetic" moment as a volunteer during wwI. ${ }^{17}$ According to Triestine scholar's own account, it was during the night of Maundy Thursday (Giovedi santo) in 1916 when he was saved by divine hand and encouraged to dedicate the rest of his life to religion. What followed were multiple spiritual conversions, leading him first from Judaism to Catholicism, then to Protestantism, and finally back to Catholicism. In this vein, Macchioro liked to assume the mantle of the spiritual guide or the prophet towards the young Ernesto. In a letter he sent from Calcutta on September 3 1935, we read:

These are great days, my son. Apocalyptic days: God is revealing himself. If we could chat, I would tell you other things that provide you with a more complete picture of the apocalypse. I feel it like an enormous power: It started with my sickness that destroyed and reconstructed me, and now it continues with the testament and with the marriage. No one can tell what the apocalypse is yet to bring and how the revelation will continue, but I believe that one thing is certain: God is with us. ${ }^{18}$

It is apparent that Macchioro felt a deep spiritual connection to his son-in-law, projecting the atmosphere of apocalypse and rebirth into their relationship.

16 Emilio Gentile, The Struggle for Modernity: Nationalism, Futurism, and Fascism (Westport: Praeger, 2003), 118.

17 Di Donato, "Introduzione," 22.

18 Di Donato, "Preistoria di Ernesto de Martino," 28. 
He described their bond, in a letter sent to de Martino in 1939, as a "spiritual symbiosis" and a "progressive fusion of two destinies and two souls." ${ }^{19}$ There is little doubt that de Martino felt quite likewise for most of the 1930s. In his first letter, he told his prophetic guide about being "saved by a personal religious experience" in his quest to study Italian myths through the lens of Rudolf Otto's numinous. ${ }^{20} \mathrm{~A}$ few years later, he mentioned a first adolescent "religious crisis" during his years in Florence, ${ }^{21}$ before he wrote the following lines in January $1939:{ }^{22}$

From now on, I should look at you with other eyes, and this means not the way one looks at the scientist or the artist, but the prophet. You might be suspicious of my enthusiasm. Nonetheless, I am certain, very certain, that the things are this way. My studies, of which you are the guardian angel, confirm it for me every day. Your existence does not solely concern the realm of my ideas, in which case it would not be that big of a deal. It concerns all of my spiritual life, my feelings, my character. I now look at things differently; I judge and feel differently. ${ }^{23}$

\section{2 \\ The Arrow of Progress and the Unification of a Ruptured Modernity in Need of Orientation}

While the letter exchange does not leave any trace of Macchioro ever offering his new son the "complete picture of the apocalypse," de Martino himself would go on to dedicate much of his academic research to the revealing of such a vision. Throughout his career, he identified the radical rupture brought about by modernity as the most fundamental factor contributing to the crisis of his civilization. The idea that modernity represents a moment of crisis would remain remarkably stable throughout de Martino's life. Consider, for instance, the following reflections stemming from the end of his life, where he makes a distinction between "traditional civilizations," which "base themselves on the intellectual intuition of a transcendent and sacred eternal truth," on the one hand, and the modern Western world, on the other. Describing it is

\footnotetext{
19 Charuty, Ernesto de Martino, 117.

20 Charuty, 117.

21 Emilia Andri, Il giovane Ernesto de Martino: storia di un dramma dimenticato (Massa: Transeuropa, 2014), 27.

22 The letter of de Martino seems to have been lost, but Macchioro cites long passages of it in a letter written in mid-February.

23 Di Donato, "Preistoria di Ernesto de Martino," 34; Charuty, Ernesto de Martino, 209.
} 
as "the only existing anti-traditional culture," a "monstrosity," and "a barbarity," de Martino elaborates his time's key attributes:

With the modern age [...], the patrimony of the eternal, metaphysical, and sacred truths has entered into crisis. Disorder, individual opinions, loss of unity, dispersion in groundless multiplicity [...] agitation, lack of superior principles. [...] Democracy is the separation of the temporal from the spiritual, the social order from the sacred [...], the formation of modern nations, another element of dispersion and of disorder, of division and contradiction in the modern civilization. ${ }^{24}$

Elsewhere, de Martino found the first signs of modernity's crisis in the Renaissance period, which he similarly described as "the source of this loss of unity." ${ }^{25}$ More importantly, he argued that the true issue might not simply lie in a loss of unity, but rather in its inability to reestablish cultural coherence: "The Renaissance was the time when the nascent modern civilization very quickly manifested an insufficient power of expansion and incorporation of the relics of the past, a defect that later on remained, at least to some extent, its constant characteristic." 26

If we look a bit deeper, it becomes apparent that this loss of unity was due to two major transformations that dominated our culture during the eighteenth and nineteenth centuries: The secularization of politics and the scientification of reason. On the one hand, it was a time during which the old Christian worldview was gradually abandoned and a new secular vision started to dominate the Western world. ${ }^{27}$ Liberalism, as a set of political ideas, arose out of the sixteenth- and seventeenth-century wars of religion and culminated "in the Treaty of Westphalia," which drastically recalibrated the balance between politics and religion in Europe. In the political realm, modernization meant that religion would be "replaced by an autonomous politics," which was "based on purely secular foundations,"28 conceived in exclusively "human terms, without

24 Ernesto De Martino, La fine del mondo. Contributo all'analisi delle apocalissi culturali (Torino: Einaudi, 1977), 496.

25 De Martino, Naturalismo e storicismo nell'etnologia, 56.

26 De Martino, 56.

27 Mark Lilla, The Stillborn God: Religion, Politics, and the Modern West (New York: Alfred A. Knopf, 2007), 6 o.

28 Bernhard Giesen, "Tales of Transcendence: Imagining the Sacred in Politics," in Religion and Politics Cultural Perspectives, ed. Bernhard Giesen and Daniel Šuber (Leiden: Brill, 2005), 94. 
appeal to divine revelation or cosmological speculation." ${ }^{29}$ As de Martino put it in some hand-written notes in the early 1930s: "Westphalia: When the interest in that which you believe in diminishes, one declares 'religious tolerance.' The peace of Westphalia only represents a decline in Christian faith, both catholic and reformed." 30

Mattias Koenig, more comprehensively, summarizes the most important modernization theories as being marked by their common emphasis on the "rationalization of previously religious world-views," "a differentiation of religion and non-religious institutions," "a pluralization and privatization of religious beliefs," "a general decline of religion," and then rightly elaborates on "the core of the classical paradigm of secularization, namely the thesis of a differentiation between politics and religion." ${ }^{31}$ In Germany, this process was accelerated after the establishment of the German Reich in 1871, which brought a further distancing from the traditional Christian worldview by means of an unprecedented urbanization and industrialization. On the other hand, these political, industrial, and economic revolutions had significant scientific consequences as they allowed for the enlightenment of culture. Of particular importance was the unprecedented collection of data. Not only did Western people learn more about their bodies and the material world surrounding them, but they also accrued a massive amount of information about other cultures and other times through historical and philological research.

These transformations in the political realm-where the sacred world of Christianity gave way to a new political vision premised on the autonomy of man - and in the scientific realm - which was marked by an unprecedented accrual of new data about the world in its full cultural and temporal reachhad important consequences for the self-depiction of Western modern humanity. Indeed, although Western culture was empowered by its new sociopolitical and scientific accomplishments, the rupture of the old worldview and confrontation with many others, caused an unprecedented "need for orientation (Orientierungsbedarf)."32

29 Lilla, The Stillborn God, 4.

30 Eugenio Maria Capocasale, "Gli appunti inediti giovanili di Ernesto de Martino per un 'Saggio sulla Religione civile"' (Napoli, Istituto Universitario Orientale di Napoli, Università degli Studi “Federico II" di Napoli, 1997), 55.

31 Mattias Koenig, "Politics and Religion in European Nation-States: Institutional Varieties and Contemporary Transformations," in Religion and Politics Cultural Perspectives, ed. Bernhard Giesen and Daniel Šuber (Leiden: Brill, 2005), 292. He mentions Peter L. Berger, Thomas Luckmann, Niklas Luhmann, and Bryan Wilson.

32 Volkhard Krech, Wissenschaft und Religion: Studien zur Geschichte der Religionsforschung in Deutschland 1871 bis 1933 (Tübingen: Mohr Siebeck, 2002), 39. Aleida Assmann, similarly, speaks of a "continuous crisis of orientation." Aleida Assmann, "Transformations of 
Modernity's preferred tool to reestablish order in its socio-political, scientific, and, ultimately, cultural self-understanding was temporal in nature. For much of modernity, at least since the Enlightenment, the single most valuable tool for making sense in this new world was "progress." Reinhard Koselleck-a wonderfully insightful expositor of modernity — has laid bare that modern man's relationship to time changed dramatically between $175^{\circ}$ and $185^{\circ}$, what he calls the Sattelzeit or Neuzeit. ${ }^{33}$ It was during this period that the Western world experienced the "temporalization of history" ("Verzeitlichung der Geschichte"). ${ }^{34}$ This meant that the term "history" was for the first time thought of as a "linear and irreversible 'arrow of time,",35 as a totalizing force capable of encompassing all the particular histories, events, and processes. ${ }^{36}$

As experts have demonstrated, in light of the overwhelming rise of alterity through new discoveries, the discipline of religious studies appropriated this new "time regime" 37 because it offered its scholars a "comprehensive paradigm for ordering the new data." 38 With Hanegraaff, we could say that "the concept of 'religion' emerged, during the early modern period, in response to a crisis of comparison caused by the increasingly overwhelming evidence for global diversity in human belief and modes of worship." ${ }^{39}$ Without much hesitation, students of religion used it to reestablish order in a godless world by locating any new culture, language, or religion that they encountered along a temporal

the Modern Time Regime," in Breaking up Time Negotiating the Borders between Present, Past and Future, ed. Chris Lorenz and Berber Bevernage (Göttingen: Vandenhoeck \& Ruprecht, 2013), 40.

33 Reinhart Koselleck, "Einleitung," in Geschichtliche Grundbegriffe, ed. Otto Brunner, Werner Conze, and Reinhart Koselleck, vol. 1 (Stuttgart: Klett, 1972), xv.

34 Reinhart Koselleck, Vergangene Zukunft: zur Semantik geschichtlicher Zeiten (Frankfurt am Main: Suhrkamp, 1979), 19.

35 Aleida Assmann, Ist die Zeit aus den Fugen?: Aufstieg und Fall des Zeitregimes der Moderne (München: Hanser, 2013), 24.

$3^{6} \quad$ Koselleck, Vergangene Zukunft.

37 The term "régime d'historicité" has been propagated by François Hartog ( $c f$. François Hartog, Régimes d'historicité: présentisme et expériences du temps (Paris: Éditions du Seuil, 2003) and has since been widely used by other thinkers concerned with modernity and its particular conception of time. See, for example, Assmann, Ist die Zeit aus den Fugen?.

38 James S. Preus, Explaining Religion: Criticism and Theory from Bodin to Freud (New Haven: Yale University Press, 1987), 149.

39 Hanegraaff, "Reconstructing 'Religion' from the Bottom Up," 598. Emphasis in original. As a thoughtful reviewer noted, it might be better to speak of an exacerbation of the crisis of comparison during the early modern period. Indeed, the problem of cultural and religious encounters not only existed much earlier in "Western" society (the rise of Christianity, the encounter with Islam), but also represents a global phenomenon (Buddhism as a transnational entity in South, Southeast, and East Asia). 
axis that was driven by progress and moved inexorably from primitive cultures to the Western world's superior sophistication. ${ }^{40}$ This became particularly evident in anthropology, where Auguste Comte's (1798-1857) positivist model of cultural development and Charles Darwin's (1809-1882) biological theory of the evolution of species found their places within the humanistic framework of "evolutionism" developed by Herbert Spencer (1820-1903).

The creation of the concept "religion" coincided with the coining of others, such as "savage," "barbaric," and "civilized." Serving the purpose of giving meaning to a disoriented civilization, these concepts turned the "heavy, tumultuous thickness of history, into an airy, die-straight thread."41 The evolutionary current of religious studies was offering orientation in response to the overwhelming number of new discoveries in space by lining them on a temporal string. As one scholar noted many years ago: While the sighting of alternate histories "encouraged men to see parallels between primitive and civilized practices," the theory of progress and evolution "drew the sting and the stimulus from the comparison by regarding the former as relics, aliens from another era." ${ }^{22}$ Since then, especially in the wake of post-colonialism, an impressive cohort of scholars from diverse disciplines, primarily history, religious studies, and anthropology, has continued to argue that modern thinkers organized special realms (cultures, natures, and people) along a temporal axis that was based on evolution. As Eric Sharpe noted for the term "religion:" "Religion became something which it had never really been before. From being a body of revealed truth, it became a developing organism." ${ }^{43}$ Thanks to these types of studies, I can move on without digging deeper into the petrified soil of our past to unearth the skeletons buried by scholars of religion. ${ }^{44}$

In the modern time regime, the political and the scientific transformations were ultimately mapped onto the model of progress. If progress provided the axis, "religion" and "liberalism," as well as "irrationalism" and "reason" were used

40 Matilde Callari Galli and Antonio Colajanni, Gli argonauti: l'antropologia e la società italiana (Roma: Armando, 2000), 192-93.

41 Daniel Dubuisson, The Western Construction of Religion: Myths, Knowledge, and Ideology, trans. William Sayers (Baltimore: Johns Hopkins University Press, 2003), 153.

42 J. W. Burrow, Evolution and Society: A Study in Victorian Social Theory (London: Cambridge University Press, 1966), 240.

43 Eric J. Sharpe, Comparative Religion: A History (London: Duckworth, 1975), 48.

44 Gustavo Benavides, "Modernity," in Critical Terms for Religious Studies, ed. Mark C. Taylor (Chicago: University of Chicago Press, 1998), 186-204; Dubuisson, The Western Construction of Religion; Louis Dumont, Essays on Individualism: Modern Ideology in Anthropological Perspective (Chicago: University of Chicago Press, 1986); Talal Asad, Genealogies of Religion: Discipline and Reasons of Power in Christianity and Islam (Baltimore: Johns Hopkins University Press, 1993). 
to indicate specific positions along the axis. Indeed, religion and irrationalism were henceforth seen as a "tradition," an inferior form of culture, relegated to some early strata of civilizational development, considered as conservative, and usually studied in cultures far removed from our own secularized world. Liberalism and science, by contrast, were considered to be "modernity," that is, progressive and future-oriented categories used to describe our own culture and its advanced principles.

\section{3 \\ The Crisis of the First World War and the Rise of Oswald Spengler's Cultural Pessimism}

Everything would change with the devastating events of WWI. With the "sacred canopy" of religious order lifted, the "traditional structures and lifeways" torn into pieces, ${ }^{45}$ the pre-modern embeddedness within fixed conceptions of time and space "emptied out," 46 and with "progress" no longer a viable option in light of the destructive historical circumstances, a new sense-making crisis ensued. ${ }^{47}$ De Martino, like many of his contemporaries, started to doubt the validity of the premises of liberalism. In unpublished archival notes, written during the early 1930s, he commented that "the liberal individual is still a slave because of the existence of nature, an evil that dodges the jurisdiction of its will, an evil that it needs to endure." Consequently, so de Martino concluded, "the liberty of the individual of liberalism [is] a useless declamation." ${ }^{48}$ As political thinkers started to doubt the validity of liberalism, scholars of religion too abruptly abandoned their faith in reason and in evolutionary theories while getting pulled into the whirlwind of crisis. ${ }^{49}$ Talk about crisis and decline was one of the most popular responses to the collapse of the progress-liberalismscience nexus. In his analysis of the discourse of the crisis of modernity during the Weimar years, Michael Makropoulos has not only identified "crisis" and "contingency" as the two key terms for this period, but also emphasized the tremendous impact of WwI on the consciousness of modernity. "The 1920s,"

\footnotetext{
45 Fredric Jameson, The Seeds of Time (New York: Columbia University Press, 1994), 84.

46 Anthony Giddens, The Consequences of Modernity (Stanford: Stanford University Press, 1990), 17 .

47 Roger Griffin, Modernism and Fascism: The Sense of a Beginning under Mussolini and Hitler (Basingstoke: Palgrave Macmillan, 2007), 48.

48 Capocasale, "Gli appunti inediti giovanili di Ernesto de Martino per un 'Saggio sulla Religione civile,"” 59 .

49 Donald Wiebe, The Politics of Religious Studies (Basingstoke: Palgrave Macmillan, 1998), 292.
} 
so he remarks, "were not in this perspective the crisis of modernity, modernity was itself the completion of the historical crisis of the modern age."50 Put differently, only with the cataclysmic failure of the myth of progress following the First World War does the crisis becomes so acute that even the past centuries are read under the category of "crisis."

As a student at the University of Naples, when the young Ernesto published his first article, he did so by standing on the shoulder of one of the twentiethcentury's greatest crisis-thinkers, Oswald Spengler (188o-1936). Spengler's eponymous The Decline of the West (1918) had a "seismological"51 impact when it was first published in 1918; hitting the "nerve of time,"52 it became an immediate bestseller in the post-WwI climate of Germany. Even Ernst Cassirer, a neo-Kantian philosopher of a radically different orientation, was impressed by the book's fortune noting that "the cause of Spengler's success is to be sought rather in the title of his book than in its contents," as it "was an electric spark that set the imagination of Spengler's readers aflame."53 Based on its pseudoscientific morphology of world history according to which each culture functions like a biological organism, moving through a series of stages that invariably culminate in a final period of destruction, it perfectly reflected the pessimistic worldview that dominated those years.

Although there existed individual voices of pessimism before the outbreak of the war-I am thinking here particularly of Jacob Burckhardt (1818-1897) and Friedrich Nietzsche (1844-1900 $)^{54}$ —and Spengler started his epoch-marking

50 Michael Makropoulos, "Krise und Kontingenz. Zwei Kategorien im Modernitätsdiskurs der Klassischen Moderne," in Die "Krise" der Weimarer Republik: zur Kritik eines Deutungsmusters, ed. Moritz Föllmer and Rüdiger Graf (Frankfurt: Campus-Verlag, 2005), 56 .

$5^{1} \quad$ Charles R. Bambach, "Weimar Philosophy and the Crisis of Historical Thinking," in Weimar Thought: A Contested Legacy, ed. Peter Eli Gordon and John P. McCormick (Princeton: Princeton University Press, 2013), 136.

Thomas Rohkrämer, Eine andere Moderne?: Zivilisationskritik, Natur und Technik in Deutschland 1880-1933 (Paderborn: Ferdinand Schöningh, 1999), 285.

53 Ernst Cassirer, The Myth of the State (New Haven: Yale University Press, 1946), 289.

54 Note that many of Fritz Ringer's mandarins, Fritz Stern's politicians of cultural despair, David Harvey's modernists, and Isaiah Berlin's Counter-Enlightenment figures were active before wwi. Fritz K. Ringer, The Decline of the German Mandarins: The German Academic Community, 1890-1933 (Cambridge: Harvard University Press, 1969); Fritz Richard Stern, The Politics of Cultural Despair: A Study in the Rise of the Germanic Ideology (Berkeley: University of California Press, 1961); David Harvey, The Condition of Postmodernity: An Enquiry into the Origins of Cultural Change (Cambridge: Blackwell, 1989); Isaiah Berlin, "The Counter-Enlightenment," in The Proper Study of Mankind: An Anthology of Essays, ed. Henry Hardy and Roger Hausheer (London: Chatto \& Windus, 1997), 243-68. While these thinkers are right in observing that certain pessimistic trends existed earlier, I tend to agree with Georg Iggers when he says, "Before the war [...] not only the broad masses, 
work before its outbreak, it was Germany's disastrous defeat in 1918 that "tilted [its] delicate balance, ${ }^{55}$ throwing the country in an unprecedented crisis. Even more, the war has been described as "the great seminal catastrophe of this century," ${ }^{56}$ as a caesura that "initiated the European self-destruction and the end of European supremacy in the world, ${ }^{, 57}$ and as the beginning of a thirtyyear long "European civil war." ${ }^{\text {" I }}$ it is therefore not surprising that Spengler's Untergang and its "epic metanarrative of how the sun of an entire civilization was setting, [turned] into an international bestseller."59

While this cultural pessimism might have been particularly prominent in Germany_-perhaps, as Ian Kershaw speculates as a consequence of the "widespread feeling of national degradation" resulting from the Treaty of Versailles (1919), the blame for the war, and the significant debt payments - the sense of crisis was a pan-European phenomenon. Consequently, Spengler was only the most prominent of a series of prophets of crisis proclaiming the West's downfall in increasingly apocalyptic tones. Italy was pulled into the war in the summer of 1915, a year after the assassination of the heir to the Austrian throne. Unsurprisingly, the nation, which already before the war was one of the "weakest of those states that had developed a minimal level of modern industrialization," 60 was "plunged into an even deeper structural crisis after the cessation of hostilities," ${ }^{\prime 61}$ which claimed the lives of six hundred thousand

but also the academic world remained relatively immune from the underlying currents of cultural pessimism." Cf. Georg G. Iggers, The German Conception of History: The National Tradition of Historical Thought from Herder to the Present (Middletown: Wesleyan University Press, 1969), 240. Similarly, Paul Fussell noted, "The Great War was perhaps the last to be conceived as taking place within a seamless, purposeful 'history' involving a coherent stream of time running from past through present to future," defining it further as the war that "reversed the Idea of Progress." Cf. Paul Fussell, The Great War and Modern Memory (New York: Oxford University Press, 1975), 8, 21.

55 Dumont, Essays on Individualism, 154.

56 George F. Kennan, The Decline of Bismarck's European Order: Franco-Russian Relations, 1875-189o (Princeton: Princeton University Press, 1979), 3.

57 Jörg Fisch, Europa zwischen Wachstum und Gleichheit: 1850-1914 (Stuttgart: Ulmer, 2002), 14

$5^{8}$ Walther L. Bernecker, Europa zwischen den Weltkriegen: 1914-1945 (Stuttgart: Ulmer, 2002), 13 .

59 Griffin, Modernism and Fascism, 212.

6o Stanley G. Payne, "Foreword," in The Struggle for Modernity Nationalism, Futurism, and Fascism, ed. Emilio Gentile (Westport: Praeger, 2003), x.

61 Griffin, Modernism and Fascism, 212. 
of its young men. Besides Spengler, who was well received in Italy, the peninsula had its own share of cultural pessimists. ${ }^{62}$

In some ways, both the prophetic figure of Macchioro and the young Ernesto were part of this group of people. This is not only apparent if we look at their correspondence, but also if we examine de Martino's writings during those years. Between 1932 and 1934, a few years after his inaugural writing on his century's most famous pessimist, the newly-minted $\mathrm{PhD}$ published three articles in which he furthered his inquiries into the crisis of his civilization ${ }^{63}$ - "Letter to the Universale" (1932), "Current Observations" (1934), and "Critique and Faith" (1934). Here too, de Martino's message remained the same: He spoke of the "days of crisis," of the "explo[sion] of the crisis of the System,"64 of the "disorientation of the consciousness facing its fate to change its own Weltanschauung 'toto caelo,"'65 and of "a crisis [...] that befalls the West to this day." 66

De Martino was aware of the fact that the change on the temporal axis- the replacement of "progress" with "decline" — had to be accompanied by a critique of the ontological and the epistemological convictions of modernity. In describing the latter, he struck up one of the most reverberant tunes of the pessimist's swan song by blaming the "excessive development of our critical faculty [which is] locking itself into the lucid concept of the philosopher" for the crisis of modernity. ${ }^{67}$ Experts have noted that de Martino's "critical faculty" can be identified with "critical reason," the "calculating and utilitarian ratio of Enlightenment origin." 68 Regarding the ontological crisis, de Martino appreciated that the conceptualization of religion is the result of a backward-looking attitude that was "armed with historicism" 69 and characterized by an exclusive "enthusiasm [for] historical considerations: One could even say that for [the

62 Domenico Conte, Catene di civiltà: studi su Spengler (Napoli: Edizioni scientifiche italiane, 1994), 144-67; Michael Thöndl, "Die Jahre der Entscheidung im faschistischen Imperium. Die Rezeption von Oswald Spengler in Mussolinis Italien," in Oswald Spengler als europäisches Phänomen der Transfer der Kultur- und Geschichtsmorphologie im Europa der Zwischenkriegszeit 1919-1939, ed. Zaur Gasimov and Carl Antonius Lemke Duque (Göttingen: Vandenhoeck \& Ruprecht, 2013), 239-62.

63 These three articles have recently been republished by Domenico Conte: Conte, "Decadenza dell'Occidente," 509-17.

64 Ernesto De Martino, “Considerazioni attuali," L'Universale 5, no. 10 (March 1934): 2.

65 De Martino.

66 Ernesto De Martino, "Critica e fede," ed. Domenico Conte, Archivio di storia della cultura 23 (1934 2010): 515 .

67 Ernesto De Martino, "La decadenza dell'Occidente," ed. Domenico Conte, Archivio di storia della cultura 23 (1929 2010): 508.

68 Andri, Il giovane Ernesto De Martino, 28.

69 De Martino, "Critica e fede," 1934 2010, 516. 
historian] only the past holds dignity and grandiosity."70 $\mathrm{He}$ also defined the darkness surrounding him as a "crisis of ideals and faith" and, citing a paragraph of Ernest Renan's The Future of Science (1891) that he "holds particularly dear," he blamed "the critical spirit" for "prohibiting chimeras by poisoning them." De Martino juxtaposed the modern conception of religion as historical fact to that of pre-modern times, when religion was conceived as myth, which is always marked by "propulsive," "enthusiastic," and based on a sense of "duty-to-be."71 As we will see in the following chapter, "civil religion," which de Martino developed as an intellectual category with political relevance, can be regarded as an attempt to revive such a pre-modern form of religion in the garb of a modern movement, namely fascism.

70 Ernesto De Martino, “Considerazioni attuali," ed. Domenico Conte, Archivio di storia della cultura 23 (1934 2010): 511.

71 Ernesto De Martino, “Critica e fede," L'Universale 4, no. 17 (September 1934): 269-83. 